\title{
Interaksi Sosial Orangtua Pekerja Industri Dalam Fenomena Daycare Di Tambun Selatan
}

\author{
Devy Putri Kussanti ${ }^{1}$, Marlinda Irwanti Poernomo ${ }^{2}$, Hayu Lusianawati ${ }^{3}$ \\ Universitas Bina Sarana Infromatika ${ }^{1}$, Universitas Sahid Jakarta ${ }^{2,3}$ \\ devy.dpk@bsi.ac.id,marlinda1610@gmail.com, hayu_lusianawati@usahid.ac.id
}

\begin{abstract}
Cara Sitasi: Devy P K, Marlinda I P, Hayu L (2021) Interaksi Sosial Orangtua Pekerja Industri Dalam
Fenomena Daycare Di Tambun Selatan 2021 21(2), 130-141 Retrieved from https://doi.org/10.31294/jc.v19i2
\end{abstract}

\begin{abstract}
Apart from being a place to leave children when both parents work, daycare is also seen as a place for child protection and fulfillment that is suitable for parents of industrial workers, especially the existence of daycare not far from the work location so as to minimize the time to pick up and drop children from work to and from work. The social interaction that occurs between the parents of industrial workers and the community in South Tambun regarding the daycare phenomenon lies in the daily life of industrial workers who have erratic working hours and have to leave their children in daycare which is seen as a daycare for city people who can afford it. This study uses a descriptive qualitative strategy or method with an in-depth interpretation of field findings based on existing facts. This research tradition is a phenomenological tradition that focuses attention on the conscious experience of an individual and uses an interpretive paradigm that seeks to find explanations about social or cultural events based on the perspectives and experiences of the person or organization under study. Using a symbolic interactionism analysis knife, the research describes three concepts, namely Mind, Self and Society from parents of industrial estate workers who leave their children in daycare.
\end{abstract}

Keywords: Symbolic Interactionism, Industrial Workers, and Daycare

\section{PENDAHULUAN}

Pada jaman modern saat ini, dalam satu keluarga tidak hanya seorang ayah saja yang bekerja, tetapi terkadang seorang ibu juga ikut bekerja dengan berbagai pertimbangan dan penyesuaian alasan mengapa seorang ibu bekerja. Karena memang di Indonesia identik pencari nafkah utama adalah seorang ayah sedangkan seorang ibu memiliki peran sebagai pendidik anak di rumah.

Dengan meningkatnya partisipasi seorang ibu turut serta bekerja baik dengan alasan menambah penghasilan keluarga, memiliki jenjang pendidikan tinggi (emansipasi), ingin membahagiakan suami dan anak dan lain sebagainya maka hal tersebut patut diapresiasikan dengan baik. Hanya saja muncul pertanyaan mendasar apabila keduanya bekerja (ayah dan ibu) maka siapa kelak yang akan menemani anak mereka di rumah?. Seorang anak merupakan aset keluarga yang wajib dijaga dengan baik dan dibentuk dengan tanggungjawab kedua orangtuanya. Hal ini dikarenakan kedepannya anak akan menjadi penerus bangsa yang menentukan masa depan dan menjunjung tinggi nilai-nilai bangsa serta Negara. Oleh sebab itu sebagai orangtua sudah seharusnya membimbing dan mengawasi anak-anak mereka dengan baik dan bertanggungjawab agar kedepannya dapat terbentuk penerus bangsa yang tidak hanya memiliki wawasan yang baik tetapi memiliki moral yang baik pula.

Sebelum seorang anak terjun kedalam dunia pendidikan formal atau sekolah, keluarga merupakan tempat awal mereka belajar. Dasar pembentukan karakter anak yang pertama adalah keluarga, dimana keluarga merupakan lingkungan pertama yang dikenal oleh anak dalam menumbuhkan eksistensi dirinya serta memberikan kontribusi yang sangat dominan terhadap terbentuknya karakter anak, yang meliputi kepribadian, kecerdasan intelektual hingga pada pembentukan karakter spiritual.

Munculnya fenomena suburban dimana masyarakat setempat memandang bahwa pendidikan anak sebaiknya diserahkan kepada keluarga dekat seperti nenek/kakeknya jika kedua orangtua bekerja, tetapi tidak dengan kondisi sebenarnya di Tambun Selatan yang mayoritas merupakan masyarakat pendatang dan dengan keterpaksaan menitipkan anak mereka di daycare dengan dalih ketika selesai bekerja dapat dijemput dan diasuh oleh kedua orangtua sendiri di rumah tanpa harus merepotkan nenek/kakeknya. Tindakan yang diambil oleh para orangtua pekerja yang menitipkan anak mereka di daycare memunculkan tanggapan atau persepsi "tidak bijaksana" dikarenakan dari adanya kehidupan pribadi pekerja kawasan yang mayoritas pendatang memiliki pendapatan tiap bulan yang berkecukupan 
hanya untuk kehidupan keseharian. Dahulu bagi pekerja kawasan perindustrian menitipkan anak di daycare merupakan hal yang kerapkali dilakukan oleh mereka yang bekerja diperkotaan ataupun pekerja kantoran. Sehingga gambaran daycare bagi para pekerja kawasan perindustrian pada awalnya sangat tinggi dan menjadi identitas kaum atas. Saat ini dengan semakin bertambahnya pengetahuan sosial dan intelektualitas pekerja kawasan perindustrian terutama bagi kepentingan anak memungkinkan bagi para pekerja kawasan perindustrian untuk menitipkan anak mereka di daycare.

Pada dasarnya masyarakat yang mengganggap "tidak bijaksana" pilihan keluarga pekerja kawasan perindustrian dalam menitipkan anak di daycare masih belum memahami bahwa dengan adanya tindakan berani tersebut semata-mata tidak hanya sebagai ajang unjuk identitas kemampuan tetapi sebagai wujud tanggungjawab mereka sebagai orangtua untuk memberikan pendidikan informal diluar rumah, memfasilitasi wadah sosialisasi yang terbaik bagi anak dan tidak merepotkan sanak keluarga seperti nenek maupun kakek yang sudah selayaknya dimasa tua menikmati indahnya kebersamaan dengan beribadah.

Keberadaan daycare memang sangat membantu para orangtua yang bekerja dan tidak memiliki sanak keluarga dekat yang bisa dijadikan tempat untuk menitipkan anak-anak mereka atau tidak memiliki asisten rumah tangga. Hingga saat ini masyarakat masih memandang daycare hanya tempat untuk menitipkan anak dan anak hanya memperoleh kegiatan keseharian mereka seperti bermain, makan siang, mengobrol, menonton televisi (acara anakanak), tidur siang dan mandi sore. Tetapi pada dasarnya menitipkan anak di daycare ternyata merupakan salah satu wujud dalam membentuk karakter anak. Hal ini dikarenakan adanya peraturan yang memperbolehkan menitipkan anak di daycare di usia 3 bulan (ketika seorang ibu sudah selesai masa cuti melahirkan), usia 3 bulan hingga 5 tahun merupakan usia golden age pada anak, dimana pada masa golden age otak bertumbuh secara maksimal, begitu pula pertumbuhan fisik. Selain itu, masa tersebut juga terjadi perkembangan kepribadian anak dan pembentukan pola perilaku, sikap, dan ekspresi emosi.

Berdasarkan uraian di atas, maka akan sangat menarik apabila penelitian dapat dengan jelas dan detail memaparkan mengenai interaksionisme simbolik pada orangtua pekerja industri dalam fenomena daycare dan mendeskripsikan pula mengenai alasan mendasar orangtua pekerja di kawasan perindustrian memilih daycare sebagai solusi untuk menitipkan anak mereka. Penelitian ini penting dilakukan agar dapat mendeskripsikan interaksi sosial orangtua pekerja industri dalam fenomena daycare khususnya di daerah Tambun Selatan dan masih minimnya penelitian mengenai subjek dan objek penelitian ini di Indonesia.

\section{METODOLOGI PENELITIAN}

Jenis penelitian ini mengambil strategi atau metode kualitatif deskriptif dengan interpretasi mendalam terhadap temuan-temuan lapangan berdasarkan fakta yang ada mengenai fenomena daycare bagi orangtua pekerja di kawasan perindustrian. Menurut (Ardianto, 2010) "penelitian kualitatif yang disebut penelitian interpretif atau penelitian lapangan adalah suatu metodologi yang dipinjam dari ilmu seperti sosiologi dan antropologi dan diadaptasi kedalam setting pendidikan".

Metode kualitatif sebagai kaedah ini memberatkan usaha untuk mencari dan memberikan keterangan serta pemerhatian bukan numerical walaupun terdapat keterangan yang merujuk kepada statistik. Kebanyakan kajian dalam bidang ini memberikan keterangan, interpretasi atau makna dalam sesuatu proses komunikasi. Kaedah ini juga lebih merupakan usaha untuk memberikan keterangan tentang sifat dan keadaan manusia dengan menggunakan pandangan umum tentang apa-apa saja tindakan sosial. Justru penyelidikan kualitatif tidak mampu tertumpu ke arah pengutipan maklumat yang banyak. Sebaliknya, kaedah ini berusaha untuk memperoleh maklumat berkualiti dengan memberikan tumpuan terhadap sampel yang kecil. (Jasmi, 2012)

Sedangkan menurut Moleong penelitian kualitatif adalah jenis penelitian yang mendekripsikan sekaligus mendekripsikan kondisi rill objek penelitian. Menurut Moleong, penelitian kualitatif adalah penelitian yang dilakukan berdasarkan prosedur penelitian yang menghasilkan data dekriptif berupa kata-kata tertulis atau lisan dari orang-orang dan perilaku serta keadaan yang dapat diamati. (Moleong, 2010)

Tradisi penelitian ini ialah tradisi fenomenologi yang memfokuskan perhatian terhadap pengalaman sadar seorang individu. Teori komunikasi yang masuk dalam tradisi fenomenologi berpandangan bahwa manusia secara aktif menginterpretasikan pengalaman mereka, sehingga mereka dapat memahami lingkungannya melalui pengalaman personal dan langsung dengan lingkungan. Tradisi fenomenologi memberikan penekanan sangat kuat pada persepsi dan interpretasi dari pengalaman subjektif manusia. Pendukung teori ini berpandangan bahwa cerita atau pengalaman individu adalah lebih penting dan memiliki otoritas lebih besar daripada hipotesa penelitian sekalipun. (Morissan, 2013)

Pada penelitian ini peneliti menggunakan paradigma interpretif. Dimana paradigma interpretif berasal dari pemikiran Jerman. Fokus paradigma ini adalah pada 
bahasa, interpretasi simbol, dan pemahaman ilmu sosial serta pemikiran manusia. Dalam sosiologi, manusia dan sosial memiliki hubungan saling mempengaruhi secara inheren. Penelitian interpretif berusaha untuk menjelaskan hubungan antara tindakan dan makna yang mana interpretasi merupakan proses aktif dan disiplin yang kreatif untuk memastikan kemungkinan makna tindakan dan pesan. (Lannai, 2014)

Pendekatan interpretif berangkat dari upaya untuk mencari penjelasan tentang peristiwa sosial atau budaya yang didasarkan pada perspektif dan pengalaman orang atau organisasi yang diteliti. Secara umum pendekatan interpretif merupakan sebuah sistem sosial yang memaknai perilaku secara detail langsung mengobservasi. (Newman, 2015). Interpretif melihat fakta sebagai sesuatu yang unik dan memiliki konteks dan makna yang khusus sebagai esensi dalam memahami makna sosial. Interpretif melihat fakta sebagai hal yang cair dan tidak kaku serta melekat pada sistem makna. Perilaku dan pernyataan dapat memiliki makna yang banyak dan dapat diinterpretasikan dengan berbagai cara. (Newman, 2015)

Pada paradigma interpretif, pendekatan yang digunakan adalah sosiologi subyektif, pendekatan yang digunakan untuk analisa sosialnya adalah subyektifisme, sehingga pokok pikiran dari paradigma interpretif ini berupaya untuk memahami, mengungkapkan dan memaknai bentuk fundamental dari pengalaman subjektif seseorang dalam kehidupan sosialnya. (Shonhadji, 2021)

Dikaitkan dengan peran ilmu sosial, menurut (Hendrarti, 2010) paradigma interpretif memandang bahwa ilmu sosial sebagai analisis sistematis atas 'socially meaningful action' melalui pengamatan langsung terhadap aktor sosial dalam latar alamiah agar dapat memahami dan menafsirkan bagaimana para aktor sosial menciptakan dan memelihara dunia sosial mereka.

Paradigma interpretif melihat fakta sebagai sesuatu yang unik dan memiliki konteks dan makna yang khusus sebagai esensi dalam memahami interaksi sosial. Dalam penelitian ini penulis ingin menjelaskan secara detail dan jelas mengenai teori sosial dalam paradigma interpretif dimana membahas mengenai hubungan antara interaksi sosial orangtua pekerja industri dalam fenomena daycare di Tambun Selatan.

\section{HASIL DAN PEMBAHASAN}

\section{Interaksionisme Simbolik}

Menurut George Herbert Mead individu sendiri yang mengontrol tindakan dan perilaku yang termanifestasikan pada tatanan realitas, sedangkan mekanisme kontrol terletak pada makna yang dikonstruksi secara sosial. Artinya diri (individu) dalam pandangan George Herbert Mead terbentuk melalui proses pemahaman dan penafsiran simbol yang yang muncul dari tindakan diri individu sendiri. Atau yang biasa sering kita kenal manusia bertindak berdasarkan faktor internal dan eksternal. (Elbadiansyah, 2014)

George Herbert Mead menyajikan diri dan fikiran sebagai fungsi dari proses sosial, pikiran ini akhirnya sampai pada suatu kesimpulan bahwa adanya kesadaran individu setelah adanya eksistensi dari masyarakat. Artinya individu tidak akan mempunyai kesadaran sampai ia telah berinteraksi dengan dan dalam masyarakat serta mengambil peran (sikap) individu yang lain. Formulasi dari pandangan ini adalah interaksi sosial mendahului pembentukan individu dengan memunculkan kesadaran yang ilustratif. (Elbadiansyah, 2014)

Interaksionisme simbolik yang dipelopori oleh George Herbert Mead menyatakan bahwa masyarakat terdiri dari sebuah jaringan interaksi sosial. Dimana anggota-anggotanya menempatkan makna bagi tindakan mereka dan tindakan orang lain dengan menggunakan simbol-simbol. Teori interaksionisme simbolik ini berawal dari asumsi sosio-psikologis seperti misalnya yang dikatakan George Simmel, "semua fenomena dan atau perilaku sosial semua berasal dari apa yang ada dalam alam pikiran individu". (Elbadiansyah, 2014)

Cara manusia mengartikan dunia dan dirinya sendiri berkaitan erat dengan masyarakatnya. Dalam teorinya Mead melihat pikiran dan diri menjadi bagian dari perilaku manusia, yaitu bagian interaksinya dengan orang lain. Interaksi itu membuat dia mengenal dunia dan dia sendiri. Mead mengatakan bahwa, pikiran (mind) dan diri (self) berasal dari masyarakat (society) atau aksi sosial (social act).

\section{Mind}

Mind adalah sebuah proses berfikir melalui situasi dan merencanakan sebuah tindakan terhadap objek melalui pemikiran simbolik. Menurut Mead pikiran atau mind muncul bersamaan dengan proses komunikasi yang melibatkan bahasa serta gerak tubuh. Pikiran muncul dan berkembang dalam proses sosial dan merupakan bagian dari proses sosial. (Griffin, 2012)

Pikiran, yang didefinisikan Mead sebagai proses percakapan seseorang dengan dirinya sendiri, tidak ditemukan di dalam diri individu, pikiran adalah fenomena sosial. Pikiran muncul dan berkembang dalam proses sosial dan merupakan bagian integral dari proses sosial. Proses sosial mendahului pikiran, proses sosial bukanlah produk dari pikiran. Jadi pikiran juga didefinisikan secara fungsional ketimbang secara substantif. Karakteristik istimewa dari pikiran adalah kemampuan individu untuk 
memunculkan dalam dirinya sendiri tidak hanya satu respon saja, tetapi juga respon komunitas secara keseluruhan. Itulah yang kita namakan pikiran. Melakukan sesuatu berarti memberi respon terorganisir tertentu, dan bila seseorang mempunyai respon itu dalam dirinya, ia mempunyai apa yang kita lain seperti konsep ingatan dalam karya Mead melalui kemampuannya menanggapi komunitas secara menyeluruh dan mengembangkan tanggapan terorganisir. Mead juga melihat pikiran secara pragmatis. Yakni, pikiran melibatkan proses berpikir yang mengarah pada penyelesaian masalah. (Ritzer and Goodman, 2014)

Makna itu dilahirkan dari proses sosial dan hasil dari proses interaksi dengan dirinya sendiri. Menurut Mead terdapat empat tahapan tindakan yang saling berhubungan yang merupakan satu kesatuan dialektis. Keempat hal elementer inilah yang membedakan manusia dengan binatang yang meliputi impuls, persepsi, manipulasi dan konsumsi. Pertama, impuls, merupakan dorongan hati yang meliputi rangsangan spontan yang berhubungan dengan alat indera dan reaksi aktor terhadap stimulasi yang diterima. Tahap yang kedua adalah persepsi, tahapan ini terjadi ketika aktor sosial mengadakan penyelidikan dan bereaksi terhadap rangsangan yang berhubungan dengan impuls. Ketiga, manipulasi, merupakan tahapan penentuan tindakan berkenaan dengan obyek itu, tahap ini merupakan tahap yang penting dalam proses tindakan agar reaksi terjadi tidak secara spontanitas. Disinilah perbedaan mendasar antara manusia dengan binatang, karena manusia memiliki peralatan yang dapat memanipulasi onyek, setelah melewati ketiga tahapan tersebut maka tibalah aktor mengambil tindakan, tahapan yang keempat disebut dengan tahap konsumsi. (Ritzer, 2011)

\section{Self}

Self atau diri merupakan fungsi dari bahasa karena dapat merespon kepada diri sendiri sebagai objek. The self atau diri merupakan ciri khas manusia. Diri adalah kemampuan untuk menerima diri sendiri sebagai sebuah objek dari perspektif yang berasal dari orang lain atau masyarakat. Diri muncul dan berkembang melalui aktivitas intraksi sosial dan bahasa juga memungkinkan orang berperan dalam percakapan dengan orang lain karena adanya simbol. (Griffin, 2012)

The self atau diri, menurut Mead merupakan ciri khas dari manusia. Yang tidak dimiliki oleh binatang. Diri adalah kemampuan untuk menerima diri sendiri sebagai sebuah objek dari perspektif yang berasal dari orang lain, atau masyarakat. Tapi diri juga merupakan kemampuan khusus sebagai subjek. Diri muncul dan berkembang melalui aktivitas interaksi sosial dan bahasa. Menurut Mead, mustahil membayangkan diri muncul dalam ketiadaan pengalaman sosial. Karena itu ia bertentangan dengan konsep diri yang soliter dari Cartesian Picture. The self juga memungkinkan orang berperan dalam percakapan dengan orang lain karena adanya sharing of simbol. Artinya, seseorang bisa berkomunikasi, selanjutnya menyadari apa yang dikatakannya dan akibatnya mampu menyimak apa yang sedang dikatakan dan menentukan atau mengantisipasi apa yang akan dikatakan selanjutnya. (Mead, 2018)

Diri, sebagai sesuatu yang bisa menjadi sebuah objek bagi diri itu sendiri, pada dasarnya merupakan sebuah struktur sosial, diri muncul dalam pengalaman sosial. Setelah diri muncul, diri dalam pengertian tertentu memberikan pengalaman-pengalaman sosial untuk diri itu sendiri, oleh karenanya kita bisa memahami sebuah diri yang sepenuhnya soliter. Namun demikian, tidak mungkin memahami sebuah diri yang muncul dari luar pengalaman sosial. (Mead, 2018)

Mead membedakan antara " $\Gamma$ " (saya) dan " $m e$ " (aku). Jika seseorang menentukan seperti apa posisinya di dalam masyarakat dan merasakan dirinya memiliki sebuah fungsi dan keunggulan tertentu, hal-hal ini didefinisikan dalam hubungannya dengan sebuah " $P$ ', namun " $T$ " bukan sebuah " $m e$ " dan tidak bisa menjadi " $m e$ ". " $P$ " adalah respon organisme terhadap sikapsikap orang lain, " $m e$ " adalah serangkaian sikap-sikap orang lain yang terorganisasi dan diasumsikan oleh seseorang. Sikap-sikap orang lain menyusun " $m e$ " yang terorganisasi dan kemudian seseorang memberi reaksi terhadapnya sebagai " $I$ ". (Mead, 2018)

Seperti namanya, teori ini berhubungan dengan media simbol dimana interaksi terjadi. Tingkat kenyataan sosial yang utama yang menjadi pusat perhatian interaksionisme simbolik adalah pada tingkat mikro, termasuk kesadaran subyektif dan dinamika interaksi antar pribadi.

Ternyata kita tidak hanya menanggapi orang lain, kita juga mempersepsi diri kita. Diri kita bukan lagi personal penanggap, tetapi personal stimuli sekaligus. Bagaimana bisa terjadi, kita menjadi subjek dan objek persepsi sekaligus? Diri (self) atau kedirian adalah konsep yang sangat penting bagi teoritisi interaksionisme simbolik. Rock menyatakan bahwa "diri merupakan skema intelektual interaksionis simbolik yang sangat penting. Seluruh proses sosiologis lainnya, dan perubahan di sekitar diri itu, diambil dari hasil analisis mereka mengenai arti dan organisasi. (Upe, 2010)

Diri adalah di mana orang memberikan tanggapan terhadap apa yang ia tujukan kepada orang lain dan di mana tanggapannya sendiri menjadi bagian dari tindakannya, di mana ia tidak hanya mendengarkan dirinya sendiri, tetapi juga merespon dirinya sendiri, berbicara dan menjawab dirinya sendiri sebagaimana orang lain menjawab kepada dirinya, sehingga kita 
mempunyai perilaku di mana individu menjadi objek untuk dirinya sendiri. Karena itu diri adalah aspek lain dari proses sosial menyeluruh di mana individu adalah bagiannya.

Bagian terpenting dari pembahasan Mead adalah hubungan timbal balik antara diri sebagai objek dan diri sebagai subjek. Diri sebagai objek ditunjukkan oleh Mead melalui konsep " $m e$ ", sementara ketika sebagai subjek yang bertindak ditunjukannya dengan konsep " $P$ '. Ciri utama pembeda manusia dan hewan adalah bahasa atau "simbol signifikan". Simbol signifikan haruslah merupakan suatu makna yang dimengerti bersama, ia terdiri dari dua fase, " $m e$ " dan " $P$ ". Dalam konteks ini " $m e$ " adalah sosok diri saya sebagaimana dilihat oleh orang lain, sedangkan " $P$ " yaitu bagian yang memperhatikan diri saya sendiri. Dua hal itu menurut Mead menjadi sumber orisinalitas, kreativitas, dan spontanitas. (Wirawan, 2012)

Kita tak pernah tahu sama sekali tentang " $I$ " dan melaluinya kita mengejutkan diri kita sendiri lewat tindakan kita. Kita hanya tahu " $I$ " setelah tindakan telah dilaksanakan. Jadi, kita hanya tahu" $P$ " dalam ingatan kita. Mead menekankan " $I$ " karena empat alasan. Pertama, " $P$ " adalah sumber utama sesuatu yang baru dalam proses sosial. Kedua, Mead yakin, didalam " $P$ " itulah nilai terpenting kita ditempatkan. Ketiga, " $P$ " merupakan sesuatu yang kita semua cari perwujudan diri. Keempat, Mead melihat suatu proses evolusioner dalam sejarah dimana manusia dalam masyarakat primitif lebih didominasi oleh "me" sedangkan dalam masyarakat modern komponen " $I$ " nya lebih besar. (Ritzer, 2011)

Pemahaman makna dari konsep diri pribadi dengan demikian mempunyai dua sisi, yakni pribadi (self) dan sisi sosial (person). Karakter diri secara sosial dipengaruhi oleh "teori" (aturan, nilai-nilai dan norma) budaya setempat seseorang berada dan dipelajari memalui interaksi dengan orang- orang dalam budaya tersebut. Konsep diri terdiri dari dimensi dipertunjukan sejauh mana unsur diri berasal dari sendiri atau lingkungan sosial dan sejauh mana diri dapat berperan aktif. Dari perspektif ini, tampaknya konsep diri tidak dapat dipahami dari diri sendiri. Dengan demikian, makna dibentuk dalam proses interaksi antar orang dan objek diri, ketika pada saat bersamaan mempengaruhi tindakan sosial. Ketika seseorang menanggapi apa yang terjadi dilingkungannya, ketika itu ia sedang menggunakan sesuatu yang disebut sikap. (Haryanto, 2012)

\section{Society}

Society atau masyarakat adalah interaksi yang terjadi pada setiap individu yang prosesnya melibatkan penggunaan bahasa atau isyarat, juga berkaitan dengan proses sosial yang ada di masyarakat. Masyarakat selalu ada dalam diri individu.
Masyarakat hanya dipandang secara umum sebagai proses sosial yang mendahului mind dan self tetapi yang terpenting bajwa disetiap diri individu didalamnya juga terdapat orang lain dan terjadi interaksi. (Griffin, 2012)

Pada tingkat paling umum, Mead menggunakan istilah masyarakat (society) yang berarti proses sosial tanpa henti yang mendahului pikiran dan diri. Masyarakat penting perannya dalam membentuk pikiran dan diri. Di tingkat lain, menurut Mead, masyarakat mencerminkan sekumpulan tanggapan terorganisir yang diambil alih oleh individu dalam bentuk "aku" (me). Menurut pengertian individual ini masyarakat mempengaruhi mereka, memberi mereka kemampuan melalui kritik diri, untuk mengendalikan diri mereka sendiri. Sumbangan terpenting Mead tentang masyarakat, terletak dalam pemikirannya mengenai pikiran dan diri.

Pada tingkat kemasyarakatan yang lebih khusus, Mead mempunyai sejumlah pemikiran tentang pranata sosial (social institutions). Secara luas, Mead mendefinisikan pranata sebagai "tanggapan bersama dalam komunitas" atau "kebiasaan hidup komunitas". Secara lebih khusus, ia mengatakan bahwa, keseluruhan tindakan komunitas tertuju pada individu berdasarkan keadaan tertentu menurut cara yang sama, berdasarkan keadaan itu pula, terdapat respon yang sama dipihak komunitas. Proses ini disebut "pembentukan pranata". Namun, Mead dengan hatihati mengemukakan bahwa pranata tak selalu menghancurkan individualitas atau melumpuhkan kreativitas. Mead mengakui adanya pranata sosial yang "menindas, stereotip, ultrakonservatif" yakni, yang dengan kekakuan, ketidaklenturan, dan ketidakprogesifannya menghancurkan atau melenyapkan individualitas. Menurut Mead, pranata sosial seharusnya hanya menetapkan apa yang sebaiknya dilakukan individu dalam pengertian yang sangat luas dan umum saja, dan seharusnya menyediakan ruang yang cukup bagi individualitas dan kreativitas. Di sini Mead menunjukkan konsep pranata sosial yang sangat modern, baik sebagai pemaksa individu maupun sebagai yang memungkinkan mereka untuk menjadi individu yang kreatif. (Upe, 2010)

\section{Masyarakat Suburban}

Menurut Kuswitoyo dalam (Goolda, 2012) wilayah suburban sering didefinisikan sebagai pinggiran kota. Wilayah suburban merupakan wilayah yang memiliki karakteristik campuran antara wilayah perkotaan dengan wilayah pedesaan. Apabila dilihat dalam suatu lingkungan daerah maka wilayah suburban merupakan wilayah yang berada di antara daerah rural dan urban. Juga jika dilihat sebagai suatu bentuk komunitas, maka suburban merupakan komunitas yang memiliki sifat ditengah-tengah rural dan urban. 


\section{Daycare}

Tempat Penitipan Anak (TPA) adalah lembaga kesejahteraan sosial yang memberikan pelayanan pengganti berupa asuhan, perawatan, dan pendidikan bagi anak balita selama anak ditinggal bekerja oleh orangtuanya (Oktaviana \& Utsman, 2015). Tempat Penitipan Anak (TPA) saat ini keberadaannya semakin dirasakan oleh masyarakat karena banyak ibu rumah tangga yang semestinya menjadi pendidik utama dan pertama bagi anak kini banyak yang bekerja diluar rumah untuk membantu memenuhi pendapatan dan kebutuhan rumah tangga sehingga perhatian kepada anak menjadi berkurang (Hoerniasih, 2017).

Pusat penitipan anak menurut (Kawai, 2017) ialah di mana anak-anak berusia 0 hingga 5 tahun menghabiskan sebagian besar jam aktif mereka dalam sehari. Sedangkan Patricia Tucker (2015) memberikan definisi daycare sebagai layanan penitipan anak adalah alternatif langsung untuk memiliki perawatan selama cuti, tetapi hubungan itu nantinya dapat menjadi pelengkap karena orang tua yang bekerja akan membutuhkan layanan pengasuhan anak selama beberapa tahun setelah cuti berakhir.

Keluarga merupakan satu-satunya lembaga sosial yang diberi tanggung jawab untuk mengubah organisme biologi menjadi manusia. Proses dalam mengubah organisme biologis menjadi organisme sosiologis membutuhkan keluarga sebagai agen. Tugas agen adalah untuk mengenalkan dan memberikan pembelajaran mengenai prototype peran tingkah laku yang dikehendaki dan modus orientasi penyesuaian diri dengan yang dikehendaki. (Rustina, 2014)

Dari sinilah maka dapat dikatakan bahwa keluarga merupakan wadah awal pendidikan bagi seorang anak dan orangtua merupakan pengajar anak pertama dalam hal pengenalan akan dunia luar. Dengan kata lain keluarga sebagai lembaga pendidikan informal bagi anak-anak. Hal ini dikarenakan melalui pendidikan formal di sekolah saja tidak cukup untuk mengajarkan anak menjadi pribadi yang lebih baik, karena dewasa ini pengaruh lingkungan dan kehidupan modern yang berkembang membuat orangtua harus lebih waspada terhadap hal-hal yang tidak baik atau cenderung negatif yang dapat masuk dalam pikiran anak.

Hanya saja waktu untuk mendidik anak bagi orangtua pekerja dapat dikatakan terbatas, terlebih yang bekerja tidak hanya ayah saja tetapi ibu pun bekerja dengan porsi waktu yang sama dengan ayah. Adanya yayasan penitipan anak (daycare) merupakan salah satu solusi bagi kedua orangtua yang bekerja dan tidak memiliki kerabat dekat untuk menitipkan anakanak selagi mereka bekerja. Terkadang dengan dalih tidak percaya dengan asisten rumah tangga dan mengingat banyaknya kejadian atau kelalaian yang diakibatkan oleh asisten rumah tangga sehingga membahayakan anak-anak-anak ketika berada dirumah menjadikan alasan daycare sebagai alternatif lain untuk menitipkan anak-anak selama mereka bekerja.

Menitipkan anak-anak di penitipan anak (daycare) disinyalir dapat mengurangi kekhawatiran orangtua, karena tempat penitipan anak (daycare) memang didirikan sebagai usaha jasa penitipan anak yang berbadan hukum dan memberikan perhatian serta perawatan bagi anak-anak yang orangtuanya bekerja. Lain halnya dengan asisten rumah tangga yang terkadang memiliki tugas ganda selain menjaga anakanak terkadang mereka dituntut untuk mengerjakan tugas rumah tangga lainnya oleh majikannya. Para orangtua yang menitipkan anak mereka di daycare juga mengharapkan anak-anak dapat bersosialisasi dengan anak-anak lainnya disana, sehingga dapat dengan mudah bergaul dan menambah teman sepermainan.

Dengan semakin terbukanya pemikiran orangtua pekerja terhadap daycare maka jumlah keberadaan daycare di tiap wilayah Indonesia dapat dikatakan semakin bersaing. Berdasarkan publikasi data Kemendikbud 2018/2019 bahwa secara keseluruhan di Indonesia terdapat kurang lebih 3.027 daycare baik negeri maupun swasta yang terdaftar. Sedangkan di Jawa Barat terdapat 155 daycare terbanyak ke-5 setelah Jawa Tengah, Jawa Timur, DI Yogyakarta dan Kalimantan Selatan. (http://publikasi.data.kemdikbud.go.id/uploadDir/isi _DCB57430-EB91-4D86-9C08-

A478A0629619_.pdf)

Para orangtua yang menitipkan anak mereka di tempat penitipan anak (daycare) pada awalnya merasa beruntung dan telah melakukan tanggungjawab mereka dengan baik, tetapi terdapat beberapa permasalahan yang terkadang luput dari para orangtua. Pihak daycare menetapkan beberapa peraturan dan persyaratan bagi orangtua dan anakanak yang akan dititipkan disana. Dengan usia minimal 3 bulan dan maksimal 10 tahun, surat keterangan yang menyatakan bahwa anak yang akan dititipkan dalam kondisi sehat dan tidak memiliki gejala penyakit bawaan serta beberapa persyaratan pendukung lainnya. Tanpa disadari ternyata fungsi dari daycare ternyata tidak hanya sebagai tempat penitipan anak melainkan juga sebagai wadah dalam membangun karakter anak itu sendiri, hal ini dikarenakan pada masa golden age waktu anak-anak lebih banyak dihabiskan di daycare sehingga mereka sudah mandiri dalam melakukan kegiatan keseharian 
dan sudah terlatih dalam hal sosialisasi dengan rekan sepermainan.

Jumlah penduduk Kabupaten Bekasi tahun 2020 berdasarkan hasil registrasi penduduk dari dukcapil mencapai 3.113.017 jiwa penduduk dengan rata-rata kepadatan penduduk sebesar 2.444 jiwa per $\mathrm{km} 2$. Wilayah yang paling padat penduduknya adalah Kecamatan Tambun Selatan (10.001 jiwa km2, sedangkan yang paling rendah kepadatannya adalah Kecamatan Muaragembong (288 jiwa per km2). Keberadaan penduduk menurut kecamatan tidak menyebar secara merata. Penduduk paling banyak berdomisili di Kecamatan Tambun Selatan yaitu $13,85 \%$ dari total penduduk Kabupaten Bekasi, sedangkan paling sedikit di Kecamatan Bojongmangu $0,89 \%$. Penduduk yang berumur 15 tahun ke atas adalah mereka yang digolongkan sebagai penduduk usia kerja. Pada tahun 2020 kelompok usia ini berjumlah 2.856 .678 orang. Dari penduduk usia kerja tahun 2020, yang termasuk angkatan kerja berjumlah 1.840 .666 orang yang terdiri dari 1.628.231 orang bekerja dan 212.435 orang pengangguran terbuka. Sedangkan jumlah penduduk bekerja menurut status pekerjaan utama dan kategori lapangan usaha di Kabupaten Bekasi pada 2020 buruh/karyawan/pegawai menempati posisi tertinggi dengan jumlah 909.570 disusul oleh masyarakat yang memiliki usaha sendiri dengan jumlah 373.071 dengan jumlah total pekerja 1.388.885 untuk laki-laki dan perempuan (https://bekasikab.bps.go.id).

Berdasarkan data diatas maka dapat disimpulkan bahwa Tambun Selatan memiliki jumlah penduduk terbanyak di Kabupaten Bekasi dan tingkat pekerja yang juga cukup tinggi baik dari kalangan laki-laki maupun perempuan. Sedangkan berdasarkan publikasi data app basis data yang penulis kutip dari http://disperindag.jabarprov.go.id/ di Kabupaten Bekasi tercatat ada 7 kawasan industri besar yang berada di Cibitung dan Cikarang, di antaranya, Kawasan Industri Jababeka, Kawasan Lippo Cikarang, Kawasan Hyundai, Kawasan EJIP, Kawasan MM 2100, Bekasi Fajar, dan Kawasan Industri Delta Mas. Sedangkan menurut https://www.daftarperusahaan.com bahwa Tambun Selatan yang terdiri dari 10 Desa/Kelurahan yakni Jatimulya, Lambangsari, Lambangjaya, Tambun, Setiadarma, Setiamekar, Mekarsari, Tridayasakti, Mangunjaya dan Sumberjaya memiliki sekitar 95 pabrik yang hingga kini masih beroperasi.

Kondisi wilayah Tambun Selatan (pinggiran kota Bekasi) terkenal dengan wilayah pekerja kawasan yang mayoritas masyarakatnya merupakan para pendatang dari daerah dan memiliki pekerjaan sebagai buruh di pabrik. Dengan sistem kerja yang kompleks dan ketat serta tidak memiliki sanak saudara atau hanya memiliki sedikit relasi di kota tujuan maka solusi yang dianggap menenangkan bagi keluarga pekerja ialah dengan menitipkan anak mereka di daycare. Hanya saja di wilayah kawasan kerapkali orangtua yang menitipkan anak mereka di daycare dipandang "tidak bijaksana" oleh beberapa rekan kerja ataupun sanak saudara. Hal ini dikarenakan konsep penitipan anak di daycare dianggap hanya untuk orang berada dan memiliki penghasilan yang lebih dari cukup untuk memenuhi kebutuhan mereka sehari-hari. Memang biaya penitipan anak di daycare dapat dikatakan tidak murah dan juga memiliki beberapa persyaratan yang wajib ditaati oleh para orangtua yang ingin menitipkan anak mereka di daycare. Tindakan yang lazim dilakukan oleh keluarga dengan kedua orangtua pekerja apabila menemui kendala perihal bagaimana dengan anak mereka ketika mereka bekerja adalah dengan memutuskan siapa yang harus tetap bekerja dan siapa yang harus mengalah menjaga anak dirumah. Lazimnya seorang istri atau ibulah yang kerapkali mengalah demi berlangsungnya kehidupan berumah tangga. Hal tersebut juga terlihat di masyarakat kawasan perindustrian di Bekasi dan bahkan beberapa dari mereka menempuh jalan lain dengan cara menitipkan anak mereka pada sanak saudara atau nenek-kakeknya apabila keputusan yang diambil adalah kedua orangtua tetap bekerja. Dengan dalih lebih aman jika ditinggal kerja hingga pada kebutuhan finansial yang tidak mencukupi untuk membayar Asisten Rumah Tangga (ART) maka dengan berat hati kedua orangtua pekerja menitipkan anak mereka di kampung halaman bersama nenekkakeknya.

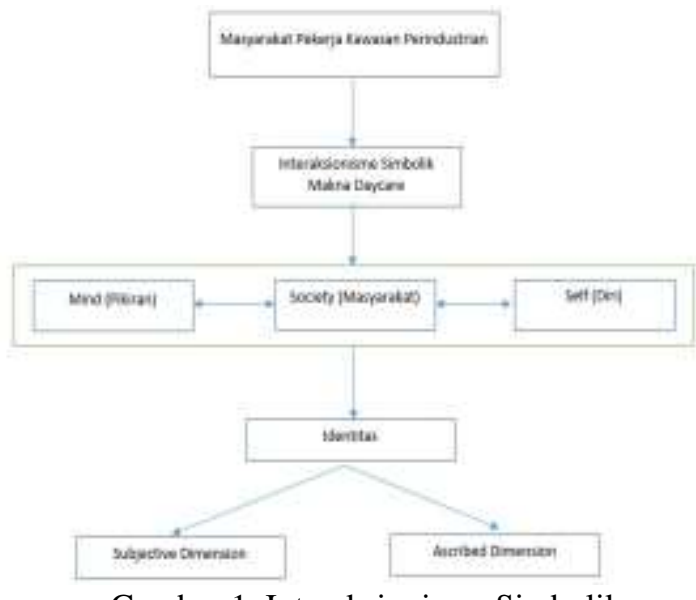

Gambar 1. Interaksionisme Simbolik

Gambar 1 diatas adalah untuk menjelaskan bahwa penelitian ini berawal dari adanya masyarakat pekerja kawasan perindustrian yang dianalisis dengan menggunakan teori interaksionisme simbolik yang dikaitkan dengan identitas mereka yang berasal dari persepsi diri dan persepsi masyarakat mengenai daycare. Dalam interaksionisme simbolik terdapat konsep yang terdiri dari Mind yang dalam penelitian ini mengacu pada proses pemikiran mengenai pekerja kawasan perindustrian yang menitipkan anak mereka 
di daycare. Sedangkan Society ialah interaksi sosial yang terjadi antara pekerja di kawasan perindustrian dengan masyarakat sekitar mengenai konsep pemahaman daycare. Dan yang terakhir adalah Self yang mengacu pada merefleksikan gambaran diri sendiri dari perspektif orang lain. Dimana respon individu nantinya akan memunculkan konsep diri baik sebagai $I$ yakni cara pandang terhadap dirinya sendiri maupun sebagai $M e$ yakni cara pandang orang lain terhadap dirinya.

Peneliti melakukan observasi awal dengan mendatangi beberapa tempat penitipan anak (daycare) yang berada di Tambun Selatan. Terdapat dua lokasi daycare yang menerima peneliti untuk melakukan penelitian, yakni Daycare Putradarma Islamic School di Jl Pisang, Tambun Selatan dan Daycare Kupu-Kupu Mungil di Sinar Kompas Utama, Tambun Selatan.

Dari kedua objek penelitian tersebut akhirnya penulis memilih daycare Kupu-Kupu Mungil sebagai lokasi objek penelitian dan memilih subjek penelitian adalah para orangtua yang bekerja di kawasan industri yang menitipkan anak mereka di daycare Kupu-Kupu Mungil. Hal ini dikarenakan waktu yang fleksibel dari pihak Kupu-Kupu Mungil dan juga para orangtua yang mayoritas memiliki pekerjaan sebagai pekerja kawasan industri (buruh pabrik).

Dalam mendapatkan data yang lengkap, peneliti melakukan pendekatan diawal dengan pihak daycare untuk meminta pesetujuan perihal nama anak yang kedua orangtuanya bekerja sebagai pekerja kawasan industri, setelah itu meminta ijin kepada pihak daycare untuk memperbolehkan peneliti berkunjung tiap sore hari untuk bertemu dengan orangtua yang hendak menjemput anak mereka. Peneliti mendatangi daycare Kupu-Kupu Mungil di sore hari (kisaran jam 16.00) agar dapat bertemu dengan beberapa orangtua pekerja industri dan meminta ijin untuk diperbolehkan melakukan tanya jawab singkat perihal nama dan nomor handphone mereka. Setelahnya peneliti menghubungi satu persatu calon infroman/narasumber untuk meminta ijin kembali perihal interview lebih lanjut, menanyakan beberapa data awal mereka dan mengambil beberapa foto untuk dokumentasi.

Untuk memaparkan dan menjelaskan hasil dari penelitian akan lebih mudah apabila diawali dengan gambaran umum seperti gambaran mengenai informan. Oleh karena itulah peneliti akan terlebih dahulu memaparkan secara ringkas perihal profil seluruh informan yang terlibat dalam penelitian. Jumlah informan pada awalnya adalah 4 orang (khususnya wanita/ibu pekerja) yang bekerja sebagai pekerja di kawasan perindustrian dan menitipkan anak mereka di daycare ketika mereka sedang bekerja (kurun waktu dititipkan minimal 5th atau minimal sejak anak mereka berumur 2 bulan).

\section{Pemikiran Dari Pekerja Industri (Mind)}

Mead menyatakan bahwa mind dapat dikatakan sebagai kemampuan fikiran seseorang yang dapat dikembangkan dengan cara berinteraksi dengan individu lainnya. Hal ini ini dikaitkan dengan konsep mind dalam penelitian ini yakni dimana pemikiran orangtua pekerja industri terhadap daycare diawali oleh pengalaman pribadi dari rekan kerja yang menitipkan anak mereka pada ART maupun dititipkan pada kakek-neneknya. Mereka diberi stimulus bahwa tidak sepenuhnya menitipkan anak pada ART akan aman, terlepas anak-anak ditinggal dengan ART di rumah sendiri yang notabene-nya wilayah atau daerah yang familiar oleh anak. Kontrol yang tidak maksimal, kurangnya sosialisasi anak dengan teman sepermainan hingga pada ketakutan akan kedekatan anak terhadap ART daripada kedua orangtuanya membuat beberapa orangtua pekerja kawasan industri menpertimbangkan kembali solusi mencari ART bagi anak mereka. Pemikiran orangtua pekerja kawasan industri merasa tidak nyaman dengan orang luar atau ART yang bekerja dirumah meskipun PP menjadikan landasan dasar ketidakinginan mereka menggunakan jasa ART.

Sedangkan ketika dititipkan kakek-neneknya di kampung halaman, hal yang seringkali menjadi pertimbangan bagi orangtua pekerja industri adalah adanya tanggapan tetangga kampung yang memberikan persepsi bahwa mereka tidak sayang pada kedua orangtua yang sudah renta, tidak bisa membahagiakan orangtua dimasa tua, masih membebani orangtua dan lain sebagainya. Hal ini dipaparkan oleh informan 2 dan Informan 1 sebagai berikut:

"Alhamdulillah kami diijinkan untuk membawa anak kami pulang ke sini (Tambun) bersama kami dengan syarat kami bisa tanggungjawab dengan baik. Kemudian Ibu saya mulai bercerita bahwa hampir setiap belanja ditukang sayur ditanya tetangga, kenapa sudah tua masih mau dititipkan cucu yang masih bayi, masa anaknya setega itu meninggalkan orangtua yang sudah renta untuk merawat cucunyakan capek merawat bayi, anaknya dosa lho bu kalau begini caranya, dll. Sebenarnya ibu saya juga merasa bosan dan tidak suka diberi komentar seperti itu tetapi karena sayang dengan anak cucu maka meskipun lelah tetap tidak bisa berbuat apa-apa." (Wawancara, 2021)

"Awalnya tidak, baru masuk minggu ketiga dititipkan di daycare baru cerita ke orangtua, karena takut diceramahi. Jaman sekarang kriminalitas kan macam-macam ya bu, jadi ya takut saja tanggapan orangtua nanti. Tapi akhirnya ketika bercerita tanggapan orangtua diluar dugaan. Mereka setuju 
cucunya dititipkan saja di daycare ketimbang dititipkan pada ART karena pengalaman keluarga dan rekan kerja yang menitipkan anak pada ART malah anaknya dekat sekali dengan ART daripada kedua orangtuanya, ketika ART tidak masuk kerja untuk menemani di rumah si anak mengamuk dan menangis agar mbk ART tersebut datang, ketika akan diajak orangtua pergi keluar pun mbk ART harus diajak. Tanpa terkecuali pada saat tidur si anak terkadang meminta ditemani oleh mbk ART ketimbang kedua orangtuanya." (Wawancara, 2021)

Pada umumnya keputusan yang akan diambil oleh orangtua pekerja industri perihal layaknya menitipkan anak mereka pada siapa dan dimana diawali dengan pemikiran mengenai kesesuaian dari si orangtua dan dari si anak itu sendiri. Orangtua pekerja kawasan industri memandang penambahan budget bulanan akan semakin membengkak dengan menitipkan anak mereka baik di daycare maupun dengan menitipkan anak di ART. Hanya saja dalil "kebutuhan" selalu mendasari tindakan yang diambil dan mengalahkan kondisi baik dari segi ekonomi maupun waktu. Dengan menitipkan anak di daycare maka pengeluaran bulanan orangtua pekerja kawasan industri akan semakin bertambah dan waktu untuk menciptakan "bounding" ke anak (bagi seorang ibu) akan berkurang. Hal ini dipaparkan oleh beberapa informan penelitian, Informan 3 dan Informan 2 yakni:

"Anak-anak butuh tempat yang nyaman layaknya dirumah sendiri tetapi dapat bersosialisasi juga dengan teman-teman seusianya. Saya waktu masukkan Yuki ke daycare memang mencari daycare sebagai tempat penitipan anak, karena kan saya butuh tempat dimana anak saya dititipkan. Tetapi saya mau tempat penitipan tidak dirumah karena saya mau waktu pulang kerja rumah masih dalam kondisi rapih dan bersih dan juga saya tidak jamin kalau sama ART anak saya dibolehkan main diluar atau temannya main kerumah, kan kasian anak jadi kesepian dan gak punya teman." (Wawancara, 2021)

"Kalau saya dan suami lebih memilih tempat penitipan anak yang bernuansa Islami dan ada fasilitas sekolah TK nya juga, supaya anak nyaman saat belajar dan juga bermain. Kalau dari lokasi sudah pasti yang searah dengan lokasi kerja, tidak jauh dari rumah dan banyak anak-anak yang sebaya. Tempat penitipannya bersih dan kamar tidurnya dipisah antara laki-laki dan perempuan-meskipun masih kecil tetap harus ada batasan. Gurunya ramah dan sayang sama anak-anak. Terjangkau juga pastinya dan ada kegiatan sehari-sehari seperti menyanyi, mewarnai, menggambar, olahraga dan lainnya." (Wawancara, 2021)

Para orangtua pekerja kawasan industri dapat dikatakan sangat membutuhkan daycare tidak hanya sebagai tempat untuk menitipkan anak mereka tetapi juga sebagai rumah kedua bagi anak-anak, hal ini untuk membuat anak-anak nyaman sekaligus dapat menumbuhkan kemandirian anak sejak kecil dengan mengisi waktu keseharian tanpa kedua orangtua.

Tambun Selatan yang masih masuk dalam kawasan Bekasi merupakan wilayah yang sangat berdekatan dengan kawasan industri seperti Cibitung dan Cikarang, memiliki atmosfer berbeda dengan wilayah Bekasi lainnya. Hal ini dikarenakan padatnya penduduk yang berdomisili di Tambun Selatan mengakibatkan banyaknya individu yang bekerja di kawasan industri sehingga operasionalisasi jalanan selalu ramai dan padat merayap setiap harinya. Kepadatan penduduk di wilayah Tambun Selatan memberikan warna lain dalam hal interaksi sosial. Seperti halnya mengenai menitipkan anak di daycare bagi orangtua pekerja industri, masyarakat Tambun Selatan memiliki beberapa pemikiran tersendiri.

Konsep mind bagi orangtua pekerja industri yang menitipkan anak mereka di daycare terhadap interaksi sosial masyarakat khususnya di Tambun Selatan memiliki penilaian bahwa orangtua sibuk bekerja (workaholic), sehingga saat hari libur dirumah pun tidak melakukan interaksi sosial di masyarakat secara maksimal.

"Karena saya orang pendatang dan rantau dari jauh, jadi saya agak kurang komunikatif dengan para tetangga, hanya saling tegur sapa dan juga senyum jika berpapasan. Sampai sekarang kalau saya tidak pernah bertamu ke rumah tetangga. Karena saya kan pergi pagi pulang menjelang maghrib, terkadang hari Sabtu masih masuk kerja, kadang lembur juga. Jadi waktu libur cuma hari Minggu dan saya pakai untuk beberes rumah dan santai-santai, kadang sih main keluar sama suami dan anak-anak, pokoknya jarang ikutan nimbrung di depan rumah kalau ada ibu-ibu pada ngobrol."

\section{Konsep Diri (Self) Pekerja Kawasan Industri}

Proses dari munculnya "diri" merupakan sebuah proses sosial yang melibatkan interaksi antar individu di dalam sebuah kelompok. Terkadang kesadaran diri terorganisasi pada individu sosial dan hal seperti ini dapat dilihat, bukan karena seseorang berada dalam sebuah kelompok sosial serta dipengaruhi oleh orang lain atau memperngaruhi orang lain, melainkan karena pengalaman sendiri sebagai diri yang dibawa kedalam tindakannya dari orang lain.

Konsep diri sebagai $I$ dalam penelitian ini terlihat dari alasan yang kemudian dilakukan melalui tindakan orangtua pekerja kawasan perindustrian dalam mempercayakan pengasuhan dan penitipan anak mereka di daycare (tempat penitipan anak). Setiap orangtua pasti memiliki pemikiran yang hati-hati atau bahkan over protected apabila hal tersebut berkaitan dengan anak mereka. Hal inilah yang mendasari tindakan dari orangtua pekerja industri dalam menitipkan anak mereka kesiapa ketika hendak akan 
ditinggal kerja. Pilihan yang diambil ialah menitipkan di tempat penitipan anak (daycare) hal ini dikarenakan adanya kesepahaman antara suami-istri pekerja industri terhadap pengambilan keputusan dan ibu pekerja industri lebih aman menitipkan anak mereka di daycare ketimbang dititipkan pada ART atau tetangga.

Hal ini diutarakan oleh salah satu pekerja kawasan industri, Informan 1, berikut pemaparannya:

"Datang ke Bekasi karena ikut suami yang ditugaskan pindah pabrik di Cikarang. Usia anak pertama baru5 bulanan, diasuh sendiri karena tidak bekerja, mau ambil ART bingung karena masih belum pastikan mau menetap dimana karena masih kontrak rumah di perumahan. Setelah fixed si Abi (suaminya) tidak akan dipindah-pindah lagi baru berani ambil rumah di daerah Tridaya, usia Falin sudah hampir 1 tahun. Karena kebutuhan semakin bertambah akhirnya memutuskan untuk masuk kerja di pabrik juga dan diterima tapi bingung lagi karena Falin siapa yang jaga nanti kalau Umi (dirinya sendiri) kerja. Akhirnya Abi kasih saran cari daycare, ketemulah daycare di Putradarma Islamic School tapi ternyata tidak bisa karena minimal anak dititipkan 4 tahun karena sekalian PG (Play Group). Akhirnya muter-muter cari lagi tidak ketemu terutama yang dekat rumah, semua ada kearah kota (Bekasi Barat), kan tidak searah sama jalan PP kerja. Cari sana-sini sama si Abi eh dapat di Kompas ada, Daycare, PG dan TK Islam Кири-Кири Mungil. Akhirnya sebelum masuk kerja udah dicoba masukin Falin disana, umur 1 tahun lebih-lah, anaknya tidak rewel, seminggu aja nangis pas ditinggal tapi kesininya anteng”. (Wawancara, 2021)

Sedangkan konsep diri sebagai $M e$ dalam penelitian ini terlihat dari kondisi dan waktu pekerja kawasan industri yang terkadang tidak menentu (adanya pemberlakuan shift) dan juga berasal dari luar kota sehingga masyarakat sekitar beropini bahwa pekerja industri sangatlah sibuk dan meskipun bekerja sebagai pekerja kawasan perindustrian tetapi mereka berpendidikan maka sudah sewajarnya menitipkan anak di daycare tidak di orangtua mereka. Pada dasarnya para orangtua pekerja industri ingin menampilkan kesan mandiri dan kuat menjadi warga pendatang, terlebih yang berkenaan dengan persoalan menjaga anak mereka, karena mereka memiliki pemikiran bahwa anak adalah tanggung jawab orangtua bukan kakek-nenek maupun saudara, sudah sewajarnya orangtua bekerja untuk anak tetapi tidak lupa juga memberikan penjagaan anak dengan baik meskipun mereka secara fisik tidak menemani keseharian anak. Hal ini disampaikan oleh Informan 4 sebagai berikut:

"Untuk alasan dan motivasi menitipkan anak di daycare lebih kepada tidak mau membuat repot orangtua di kampung, karena sudah tua dan juga mau mereka bahagia dimasa tua, ibadah dan jaga kesehatan saja. Sudah sewajarnya kami sebagai orangtua dari anak-anak kami ya bertanggung jawab dalam hal mendidik, melindungi dan memberikan yang terbaik bagi anak-anak kami, layaknya orangtua kami dulu. Hanya saja karena kami berdua bekerja jadi tidak ada yang dititipkan untuk menjaga anak jadilah kami menitipkan di tempat penitipan anak (daycare)". (Wawancara, 2021)

\section{Perilaku dalam Interaksi Sosial di Masyarakat (Society)}

Masyarakat (society) menurut Mead ialah jejaring hubungan sosial yang diciptakan oleh individuindividu. Untuk dapat melakukan komunikasi yang baik maka seseorang harus dapat memaknai simbolsimbol yang digunakan dalam interaksi dalam masyarakat tersebut. Mead menyebutkan bahwa simbol yang signifikan memiliki sifat verbal seperti bahasa dan juga non verbal yakni gerak tubuh. (Litttlejhon, 2014)

Orangtua pekerja kawasan industri yang pada dasarnya memiliki waktu kerja tanpa tentu (terkadang Sabtu atau Minggu masuk kerja bahkan terkadang lembur penambahan jam kerja Senin-Jumat) tidak intens melakukan kegiatan atau interaksi sosial di masyarakat sekitar. Tetapi dengan keterbatasan waktu yang dimiliki mereka masih menyempatkan diri untuk berpartisipasi dalam kegiatan sosial di RT atau RW jika waktu memungkinkan.

Interaksi yang dibangun dan diciptakan oleh orangtua pekerja kawasan industri terhadap lingkungan sekitar terkadang sebagai kamuflase dan hanya menandakan bahwa mereka ada, hal ini terlepas dari keberadaan mereka benar-benar warga masyarakat di wilayah tersebut (bukan warga yang mengontrak perumahan).

Konsep society terhadap orangtua pekerja kawasan industri yang menitipkan anak di daycare, lingkungan memberikan beberapa persepsi yang berbeda, baik yang positif maupun yang negatif. Persepsi atau penilaian dari individu lainnya memberikan sebuah makna dan kesan bahwa yang melekat pada diri seseorang adalah sebagai sebuah identitas. Informan 3 dan Informan 2 memaparkan:

"Kalau untuk masalah ini saya sebenarnya tidak memberitahu tetangga ataupun masyarakat yang ada dilingkungan sekitar, hanya saja terkadang dari sapaan tetangga yang kemudian mengajak mengobrol jadi semuanya jadi melebar kemanamana, termasuk informasi mengenai saya menitipkan anak di daycare. Sempat tetangga sebelah menimpali obrolan saya bahwa dia berhenti bekerja demi menjadi ibu rumah tangga, karena suaminya tidak percaya pada siapapun yang mendidik anaknya dan orangtua terlebih seorang ibu memiliki tanggungjawab yang besar dalam mendidik anakkarena madrasah pertama anak adalah kedua orangtuanya. Ia menyatakan bahwa pilihan dia 
bijaksana dan pilihan saya yang menitipkan anak di daycare juga bijaksana, karena pilihan seseorang itu kan tanggungjawabnya kembali pada orang tersebut. Tapi tetap dia menggaris bawahi bahwa sebaikbaiknya tangan adalah tangan seorang Ibu. Saya hanya menanggapi dengan senyuman saja bude." (Wawancara, 2021)

"Awalnya tetangga tidak tahu kalau anak-anak dititipkan di daycare, tetapi lama kelamaan tahu karena waktu berangkat dan pulang selalu bareng sama saya atau ayahnya. Tetangga saya fikirnya anak-anak saya bawa ke kantor. Lama kelamaan mereka tahu kalau anak saya dititipkan di daycare waktu arisan RT tepatnya, salah satu tetangga tanya kesaya dan tanggapan tetangga saya baik dan malah bertanya perihal biaya menitipkan anak di daycare berapa, di daycare mana, aman tidak selama dititipkan disana, sekolahnya bagaimana, makanya bagaimana dan banyak pertanyaan. Beberapa yang mendengar nimbrung dan bertanya kenapa tidak cari mbak yang nungguin saja atau dititipkan di orangtua saya, lebih aman karena kalau di daycare takutnya banyak anak-anak nanti kalau berantem gimana, kan tidak semua anak terpantau sama pengasuhnya dan kalaupun dititip kakek neneknya kayak saya ini jadi anak bisa nemenin kakek neneknya disana bu." (Wawancara, 2021)

Melalui beberapa penekanan terhadap persepsi yang diberikan oleh lingkungan sekitar dapat dikatakan bahwa orangtua pekerja kawasan industri yang menitipkan anaknya di daycare pada awalnya tidak secara langsung memberikan statement atau informasi bahwa mereka menitipkan anak mereka di daycare. Hal ini menyatakan bahwa informasi digali secara mendalam guna mendapatkan validitas yang kemudian membentuk sebuah persepsi yang dikategorikan dalam persepsi positif maupun negatif.

\section{KESIMPULAN}

Adanya persepsi masyarakat suburban terhadap pekerja perindustrian yang menitipkan anak mereka di daycare, dengan berbagai pertimbangan seperti tidak adanya keluarga yang dapat dimintai tolong untuk diititipkan anak hingga pada ketidakenakan hati karena orangtua yang sudah tua seharusnya tidak dibebani untuk mengurus cucu maka keputusan menitipkan anak di daycare menjadi solusi yang dianggap terbaik bagi pekerja perindustrian meskipun pada kenyataan menitipkan anak di daycare tidak semudah yang dibayangkan. Terdapat beberapa persyaratan yang wajib dipenuhi oleh orangtua dan juga anak yang akan dititipkan serta pembayaran jasa daycare yang tergolong tidak murah, hal ini dikarenakan daycare tidak hanya sebagai lembaga penitipan anak tetapi juga sebagai lembaga edukasi dasar agama dan etika, sosialisasi dan juga adaptasi anak terhadap lingkungan sekitar, yang seharusnya semua hal tersebut di dapatkan anak-anak dari kedua orangtua mereka.

Dengan adanya tempat penitipan anak (daycare) di Tambun Selatan membuat para orangtua pekerja kawasan industri merasa sedikit lega karena mereka mendapatkan solusi yang baik. Hanya saja konotasi menitipkan anak di daycare menimbulkan berbagai persepsi di masyarakat sekitar. Dalam penelitian ini telah terungkap konsep dasar dari kajian interaksionisme simbolik yang meliputi mind, self dan society. Konsep pemikiran (mind) pada interaksi sosial orangtua pekerja kawasan industri di Tambun Selatan mengenai daycare cenderung pada pengeluaran yang bertambah, dimana penghasilan yang tidak besar atau hanya dapat mencukupi kebutuhan bulanan harus ditambahkan biaya membayar daycare, meskipun menurut orangtua pekerja industri hal tersebut merupakan kebutuhan tetapi tidak halnya dengan masyarakat sekitar, beberapa individu di masyarakat masih memiliki pemikiran bahwa tidak mengasuh anak dengan tangan sendiri merupakan suatu hal yang tidak bijaksana.

Sedangkan pada konsep self, secara I orangtua pekerja kawasan industri ingin menampilkan kesan mandiri sebagai warga pendatang dan juga sebagai orangtua yang bertanggungjawab pada anaknya dengan memberikan wadah bermain dan berteduh yang nyaman bahkan disaat orangtua sedang sibuk bekerja. Dalam konsep self sebagai $M e$, interaksi sosial yang dilakukan oleh orangtua pekerja kawasan industri dibayangi oleh latarbelakang pendidikan. Masyarakat membentuk pandangan bahwa daycare biasanya hanya untuk orang perkotaan dan orang berpendidikan tinggi oleh karena itulah meskipun bekerja di kawasan industri tetapi karena berpendidikan tinggi maka segala sesuatu difikirkan secara matang dan seksama oleh orangtua dalam hal menitipkan anak di daycare yang layak.

Pada hubungan individu dengan masyarakat yakni society, terdapat beberapa persepsi yang membentuk identitas bagi orangtua pekerja kawasan industri yang menitipkan anak mereka di daycare. Masyarakat memberikan persepsi baik dan kurang setuju mengenai konteks menitipkan anak di tempat penitipan anak, hal yang tercermin dalam masyarakat bahwa dengan menitipkan anak di daycare maka waktu orangtua pekerja kawasan industri terbilang sibuk dan kurang memperhatikan permasalahan di sekitar lokasi tempat tinggal.

\section{REFERENSI}

Ardianto, Elvinaro. (2010). Metode Penelitian untuk Public Relations: Kuantitatif dan Kualitatif. Bandung: PT Simbiosa Rekatama.

Elbadiansyah, Umiarso. (2014). Interaksinasionalisme Simbolik Dari Era klasik 
Hingga Moderen. Jakarta: PT Rajagrafindo Persada.

Goolda. (2012). Analisis Pengaruh Fenomena Suburbanisasi Terhadap Pdrb Bekasi. Tesis. Fakultas Ekonomi Program Magister Perencanaan Dan Kebijakan Publik Universitas Indonesia. Jakarta. http://lontar.ui.ac.id/file?file=digital/20314460T\%2031211-Analisis\%20pengaruhfull\%20text.pdf

Griffin. (2012). A First Look At Communication Theory. New York: McGraw-Hill Companies.

Haryanto, Sindung. (2012). Spektrum Teori Sosial Dari Klasik Hingga Postmodern. Yogyakarta: Ar-Ruzz Media.

Hoerniasih, N. (2017). Pengelolaan program taman penitipan anak plamboyan 3 di kabupaten kerawang. Diperoleh pada tanggal 17 Februari 2019 http://journal.unnes.ac.id/sju/index.php /jnfc

Jasmi, K. A. (2012). Penyelidikan Kualitatif dalam Sains Sosial in Kursus Penyelidikan Kualitatif siri 12012 at Puteri Resort Melaka on 28-29 Mac 2012. Organized by Institut Pendidikan Guru Malaysia Kampus Temenggong Ibrahim, Jalan Datin Halimah, 80350 Johor Bahru, Negeri Johor Darul Ta'zim.

Kawai, K. (2017). "Current Situation of Acoustic Environment in Childcare Facilities in Japan: A Comprehensive Survey in Kumamoto City Region"e, Regional Conference on Acoustics and Vibration, 1.

Lannai, D., M. Sudarma, G. Irianto, dan U. Ludigdo. (2014). "Phenomenology Study About Performance Meaning At Indonesia Foundation (Case Studies At Wakaf Foundation Of Indonesian Muslim University)." International Journal of Business and Management Invention, Vol. 3, No. 5, hlm 8-16.

Littlejohn, Stephen W. dan Foss, Karen A. (2014). Teori Komunikasi Theories of Human Communication. Edisi 9. Jakarta : Salemba Humanika.

Mead, George Herbert. (2018). Mind, Self and Society (Pikiran, Diri dan Masyarakat). Yogyakarta: FORUM

Moleong. (2010). Metodologi penelitian Kuantitatif. Bandung; Remaja Rosda Karya.

Morissan. (2013). Teori Komunikasi Individu Hingga Masa. Edisi Pertama. Jakarta: Kencana.

Newman, LW. (2015). Metodologi Penelitian Sosial: Pendekatan Kualitatif dan Kuantitatif. Jakarta: PT Indeks.

Oktaviana, M. E., \& Utsman. (2015). Proses pengasuhan taman penitipan anak (Studi pada taman penitipan anak Dewaruci Kids Kecamatan Demak Kabupaten Demak). http://jornal.unnes.ac.id/sju/index.php/jnfc

Patricia Trucker and others. (2015). Physical Activity at Daycare: Childcare Providers "Perspectives for Improvementse ${ }^{e}$. Journal of Early Childhood Research. 9.3 (2015). 211

Ritzer, George and J Goodman, Douglas. (2014). Teori Sosiologi Modern (edisi ke-7). Jakarta: Kencana Prenada Media Grup.

Ritzer, George. (2011). Sosiologi Ilmu Berparadigma Ganda. Jakarta: CV. Rajawali Pers.

Rustina. (2014). Keluarga Dalam Kajian Sosiologi. Jurnal Musawa IAIN Palu. vol. 6, no. 2, 2014, pp. 287-322.

Shonhadji, Nanang. (2021). Penggunaan Teori Sosial Dalam Paradigma Interpretif Pada Penelitian Akuntansi. Jurnal Kajian Akuntansi, Vol. 5 No. 1 2021, 49-68 e2579-9991, p2579-9975 http://jurnal.ugj.ac.id/index.php/jka.

Upe, Ambo. (2010). Tradisi Aliran Dalam Sosiologi Dari Filosofi Positivistik Ke Post Positivistik. Jakarta: Rajagrafindo Persada.

\section{BIODATA PENULIS}

Devy Putri Kussanti, S.Sos, M.Si. Lulus Sarjana Ilmu Komunikasi di Universitas Mercu Buana Jakarta tahun 2006 dan S2 Ilmu Hubungan Internasional di Universitas Indonesia tahun 2009. Menempuh S2 kembali di Usahid Jakarta pada program Magister Ilmu Komunikasi dan lulus pada tahun 2021. Profesi sebagai dosen Fakultas Komunikasi dan Bahasa Universitas Bina Sarana Informatika Program Studi Hubungan Masyarakat.

Dr. Marlinda Irwanti Poernomo, M.Si. Lulus Sarjana di UII Yogyakarta pada Ilmu Ekonomi tahun 1986 dan Sarjana di UGM Yogyakarta pada Ilmu Hubungan Internasional tahun 1987. Kemudian di tahun 1997 lulus S2 UI Jakarta pada Ilmu Kajian Perempuan dan S3 UIN Jakarta pada Dakwah Ilmu Komunikasi di tahun 2011. Saat ini menjabat sebagai Direktur Sekolah Pascasarjana Usahid Jakarta.

Dr. Hayu Lusianawati, S.Tp., M.Si. Lulusan Fakultas Teknologi Pertanian Institut Pertanian STIPER Yogyakarta (1999). Gelar S2 diperoleh tahun 2010 dari Sekolah Pasca Sarjana Universitas Sahid Jakarta. Pada 2019 menyelesaikan program Doktoral pada Universitas Sahid Jakarta dan sejak 2013 hingga saat ini sebagai dosen di Fakultas Ilmu Komunikasi Universitas Sahid Jakarta. 